\title{
Insights into the process of changing sourcing strategies
}

\author{
Wouter Faes \\ University of Hasselt, Diepenbeek, Belgium, and \\ Paul Matthyssens \\ University of Antwerp, Antwerp, Belgium
}

\begin{abstract}
Purpose - The aim of this article is to identify the motivations driving the process of changing sourcing strategy from single sourcing to multiple sourcing or vice versa.

Design/methodology/approach - Ten cases of sourcing strategy change were investigated. A qualitative research method is used to uncover the richness of these change processes.

Findings - Most of the advantages and disadvantages stated in the literature were confirmed. Identical objectives (cost cutting and quality improvement) were present in all cases, although changes took place in opposite directions. Contextual factors, such as standardisation and supplier base reduction efforts shape purchasing strategy more than previously thought. The dynamic nature of the product lifecycle also seems to be an important determinant.

Research limitations/implications - Although the results of qualitative case study research can only be "generalised" in a limited way, the case details help to identify the dynamics of sourcing strategy switches and to interpret the rationale behind these moves. Confirmatory follow-up research covering both the demand and supply side of the market is needed.

Practical implications - Switching sourcing modes is of strategic relevance to managers as lifecycle costing strategies are influenced by them. Managers should plan these decisions more effectively, evaluating the factual pros and cons of a proposed sourcing mode switch and taking the dynamics of supply markets into account.

Originality/value - The importance of the different motives for sourcing strategy changes clearly varies with the dynamism of the context (market situations and strategic intentions of buyers). A model linking the buyers' portfolio matrix to the product life cycle on the supply market is proposed.
\end{abstract}

Keywords Single sourcing, Purchasing, Sourcing, Strategic change, Supplier evaluation

Paper type Research paper

An executive summary for managers and executive readers can be found at the end of this issue.

\section{Problem statement}

One of the most important strategic problems facing purchasing managers is the selection of an appropriate number of suppliers for each product purchased. Several solutions have been presented in literature, ranging from single sourcing via dual and parallel sourcing (Richardson, 1993) to multiple sourcing. Each strategy has its advantages and drawbacks. Most of the research takes a static approach to purchasing strategy and considers the chosen sourcing option to be relatively stable over time. But strategies do change. So far, only Dubois and Gadde (1996) and Araujo et al. (1999) have depicted changes in sourcing strategies. In this paper the existing literature is complemented by identifying changes in sourcing strategy and by investigating the following questions:

The current issue and full text archive of this journal is available at www.emeraldinsight.com/0885-8624.htm

Journal of Business \& Industrial Marketing 24/3/4 (2009) 245-255

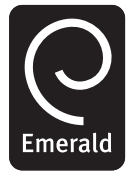

(C) Emerald Group Publishing Limited [ISSN 0885-8624] [DOI 10.1108/08858620910939796]
- What causes a company to change from one sourcing strategy to another and what outcome effects are intended?

- When (in which circumstances) do the changes in sourcing approach occur?

First the literature review is discussed. Next we describe the methodology and present the main findings. Finally, conclusions, recommendations and implications for further research are given.

\section{Literature review}

Sourcing decisions have recently gained in strategic importance. As companies are under constant pressure to outperform increasingly fierce competition, cost effectiveness, innovative capability and quality consciousness in the supply chain offer opportunities for achieving competitive advantage (Towill, 1997; Juttner et al., 2007). Strategic sourcing must thus incorporate capability assessments of the supply partners and total cost of ownership considerations when comparing different alternative partners (Talluri and Narasimhan, 2003; Swift, 1995). Zeng (2000) emphasizes the impact of sourcing on a firm's growth and profit and provides a short review of different global sourcing strategies (multiple, single and hybrid network).

Most of the literature (Bhote, 1989; Schorr, 1992; Gadde and Hakansson, 2001) compares multiple sourcing as a 
strategy with single sourcing. In multiple sourcing the buying company is splitting its orders for the same item among different available sources, whereas single sourcing is an extreme form of source loyalty towards one single supplier within a range of acceptable sources. Freeman and Cavinato (1990) and Stork (1999a, b) suggest that single sourcing is the ultimate stage of full partnerships between buyers and sellers on industrial markets. It is, amongst others, the result of the numerous "total quality programs", supplier base reduction efforts, total cost cutting strategies and reducing throughput time projects in purchasing (Owens et al., 1994; Carter et al., 2000; Buttack, 2001). Gadde and Hakansson (2001) describe how "network sourcing" implies trade-offs between involvement and sourcing opportunism.

Other literature compares the theoretical advantages and inconveniencies of different sourcing strategies (Treleven, 1987; Segal, 1989; Han et al., 1993; Porter, 1999; Zeng, 2000). In general most authors attribute more advantages than disadvantages to a single sourcing strategy (Sriram and Mummalaneni, 1990).

Single sourcing is often preferred to multiple sourcing because of an imminent cutting of costs. Single supplier-buyer relationships offers different cost advantages. As volumes are not split between different sources, the buyer has the opportunity of negotiating better purchasing conditions (Ellram and Billington, 2001; Buttack, 2001; Brierly, 2001). Less investment in warehousing is needed as delivery schedules do not have to be split and deliveries can more easily be planned (Kelle and Miller, 2001). The administrative costs of handling just one supplier are obviously lower (Schorr, 1992; Cooke, 1998; Brierly, 2001). Buyer and supplier can finally also achieve cost reductions in the logistics field (Lynch, 2001).

Moreover, improvements in quality are noticed (Sriram and Mummalaneni, 1990). This is due to the fact that the supplier is capable of managing operations more efficiently and acquiring more expertise in developing solutions for technical, logistic and other problems (Clayton, 1998). Improved products and better quality result from that. A strict prerequisite for realising this benefit is that a lot of detailed attention is paid to the selection and evaluation of the suppliers' performance. Certification is considered to be a very effective way in achieving this (Kulchitsky, 1998). Larson and Kulchitsky (1998) report both cost reductions and quality improvements resulting from single sourcing. Automotive companies are therefore increasingly relying on single sourcing to safeguard their global competitive position (Pfaffman and Stephan, 2001).

Dependency of both partners on one another is the one major drawback associated with a single sourcing strategy. It may lead to higher switching costs (as suppliers will want to create captive customers). Potentially less competitive coststructures (Treleven, 1987; Schorr, 1992; Porter, 1999; Haywood, 2001) might also result. As it may become cumbersome and costly to change supply partnerships, the buyer might loose market feeling. Knowledge of supply alternatives might fade. Thus the flexibility of the supplier might shrink and cost and price competitiveness might be gradually reduced (Biong et al., 1996; Porter, 1999; Stork, 1999b; Talluri and Narasimhan, 2003).

To overcome these drawbacks, (even Japanese) large customers frequently adopt a dual sourcing strategy (limiting the number of suppliers for an item to two) or a mixed strategy (Sugihara and Tanaka, 1994; Dirks et al., 2000; Talluri and Narasimhan, 2003) in which they deliberately choose a single source of supply for one specific item or component, but introduce competition on the level of a family of related components, thus obliging single sources to constantly improve their performance (Keough, 1993; Asmus and Griffin, 1993; Richardson, 1993). This is called parallel sourcing (Gadde and Hakansson, 2001). It is a specific form of multiple sourcing, which has been incorporated in traditional cascade like supplier associations used by Japanese firms (for instance, in the Japanese electronics industry, Hirakubo and Kublin, 1998). It has become a consistent part of Japanese network buying, which originally presupposed single sources only (Dirks et al., 2000).

There is contradictory evidence as to the effectiveness of both parallel and dual sourcing as compared to single sourcing. Watts et al. (1995) hypothesize that parallel and dual sourcing lead to the best purchasing results in cases of service buying and in high-tech markets. Single sourcing would be the best alternative in innovative technology contexts and expertise-oriented settings. On the contrary, Hines (1995) and Brandes and Lilliecreutz (1997) still find single sourcing to be the best alternative. Specifically where large outsourcing companies rely heavily on small and medium subcontractors (as is the case in Japanese network buying) single sourcing holds advantages over multiple sourcing.

Dubois and Gadde (1996) and Araujo et al. (1999) have studied buyer-supplier relationships over longer periods of time. They conclude that for the same product different supply strategies may be used alternately and pose that this probably occurs according to the importance of contextual factors, such as specifications by the final customer, standardisation efforts, increased external and internal pressure for cost savings, structural changes in the supply market, and so on ... Quayle $(1998,2002)$ cites the same reasons for purchasing strategy changes in the public sector. The variety of supply strategies these authors have observed is contrary to all expectations and very large. Stability and change are simultaneously present in partnering strategies (Gadde and Mattson, 1987; Ford, 2002).

In summary, the sourcing literature so far has mainly described the different existing sourcing strategies and their respective advantages and disadvantages. The conclusions of this research are very robust and consistent across authors. Limited evidence has been gathered however on the dynamics of these strategies. The underlying rationale for observed strategy mode switches have not been investigated intensively.

This research tries to close this gap and looks more closely into this observed dynamism. It asks more specifically why companies change from one sourcing strategy to another and what they expect from it. This dynamism is investigated at the moment of "change" itself. It is our objective to contribute to the existing literature on supply strategies in two ways:

1 Obtain more inside knowledge of the underlying reasons and intended effects when companies change sourcing strategies.

2 Link the moments of strategy change to both the market situations in which they seem to occur and the kind of strategic situation in the purchasing portfolio[1]. 


\section{Methodology}

The purpose of this research was to investigate sourcing strategy changes and their underlying rationale in more detail. Zeng (2000) describe some of the factors influencing sourcing decisions in general. They are both external and internal in nature. Among the external factors the nature and structure of the supply market and the risk involved in obtaining the materials are specifically mentioned. The buying cost involved in getting the material, the internal cost in obtaining the product, the logistics and qualitative specifications and the type of partnership preferred are mentioned as internal factors. Most of those factors are corroborated by the fact that they reoccur as advantages or disadvantages of single, multiple, dual or parallel sourcing strategies. We have used these influencing factors as the theoretical framework for our research as well.

Qualitative research is most suitable approach for this venture as the underlying research stream on dynamic purchasing strategies is still in an exploratory stage[2]. Moreover, contrary to previous quantitative research, such a methodology is capable of providing insight into the reasons why such a variety of often-conflicting observations on the dynamism of sourcing strategies is observed. Finally it provides a "rich" description of managerial practice enabling the formulation of research propositions for future large scale surveys and in-depth analyses.

To overcome the main critique mentioned about qualitative research, namely the lack of methodological rigor (Yeung, 1995), we have paid extensive attention to the robustness of the multiple case study methodology using methodological prescriptions from Eisenhardt (1989), and Miles and Huberman (1994). As this study takes a closer look at the differences in motives and at the expected advantages and disadvantages of these strategy changes, a topic list based on the framework (see appendix A) mentioned above was used throughout the interviews, starting from general identification issues, leading into motives and hindrances, and digging into the context of the switching process.

We have tried to map real, embedded events. We were able to secure active cooperation by six companies explaining ten strategy changes for our research. They stem from different sectors of industry (see Table I) and gave us insight in recent changes in sourcing strategy.

The main criteria for company selection were size (minimum number of employees) and the existence of a separate purchasing department reporting directly to company management (to assure a certain degree of confidence in the autonomy of the strategic decision taking). Case selection was in the hands of the interviewees as we let them speak freely. Recent completion of strategy change however was insisted upon as primary case selection criterion as we believe that people are more likely to remember details of what happened recently. We specifically asked our respondents to omit examples of items of little importance and volume.

Data source triangulation was aimed at to enhance the internal validity of our study. In all companies, at least two respondents (believed to be the two best-informed persons, identified during the company-selection process) were asked to identify important recent cases of sourcing mode change and then interviewed on how they thought the process had occurred, which positive factors and barriers had influenced it, who had played a role in it and what the intended and
Table I Data sources per case company (triangulation)

$\begin{array}{ll}\begin{array}{l}\text { Company } 1 \text { (pharmaceuticals), } \\ \text { one strategy change }\end{array} & \begin{array}{l}\text { Procurement manager } \\ \text { Demand planner } \\ \text { Internal purchasing documents }\end{array} \\ \begin{array}{ll}\text { Company } 2 \text { (chemicals), two } \\ \text { strategy changes }\end{array} & \begin{array}{l}\text { Plant manager } \\ \text { External (supplier) documents }\end{array} \\ \begin{array}{l}\text { Company } 3 \text { (food/drinks), two } \\ \text { strategy changes }\end{array} & \begin{array}{l}\text { Procurement manager } \\ \text { Internal purchasing documents }\end{array} \\ \begin{array}{l}\text { Company } 4 \text { (food/drinks), two } \\ \text { strategy changes }\end{array} & \begin{array}{l}\text { Corporate logistics manager } \\ \text { Purchasing manager }\end{array} \\ \text { Company } 5 \text { (steel), two } & \text { External supply market documents } \\ \text { strategy changes } & \begin{array}{l}\text { Purchaser } \\ \text { General manager } \\ \text { Internal purchasing documents }\end{array} \\ \text { Company } 6 \text { (steel), one strategy } & \begin{array}{l}\text { Assistant general manager stainless } \\ \text { change }\end{array} \\ & \text { steel } \\ \text { Internal and external documents }\end{array}$

achieved results were. They were asked to substantiate their account of the process by documented evidence and transcripts of events during the process, such as protocols of meetings and so on ... In this way, company or supplier/ external documents were used as far as possible in addition to the data of the interviews (Table I).

All interviews lasted between one and one and a half hour. Extensive notes were taken during the interviews independently by two researchers to enhance the reliability of the data thus gathered. Summaries were compared and brought together in one written transcript. Managers were then asked to give feedback on these transcripts. In case of different interpretations of the data, all interviewed people were asked again to verify whether our structured account was correct.

The revised transcript was then used for a second wave of interviews, in which the same people were asked to comment further and to clarify vague points. In this verification stage, a modified topic list was used and deeper questions were asked to the interviewees, whenever some elements needed more clarification after the first interview. The interviewers deliberately tried to lead the interviewee to areas left open in the first stage or still to be debated about. These findings were, whenever possible again complemented by secondary materials on the cases discussed about.

\section{Findings}

In our research we analysed ten case situations in which a transfer from one sourcing strategy to another one occurred. Three of the cases illustrate a strategy change from single sourcing to multiple sourcing, whereas seven of them show the reverse approach. In general this reflects the fact that cases in which a single sourcing strategy is abandoned might be more infrequent in nature due to the often mentioned trend towards more stable relationships with fewer suppliers, a fact which is moreover expected to be of a continuous nature over the next decade (Carter et al., 2000).

In Tables II and III we summarise the most important case characteristics, as well as the stated reasons for change and expected benefits and feared inconveniences. 
Table II Cases in which a strategy change took place from single to dual or multiple sourcing

\begin{tabular}{|c|c|c|c|}
\hline Case & $\begin{array}{l}\text { Reasons for changing supply } \\
\text { strategy }\end{array}$ & Advantages expected to be gained & Anticipated disadvantages \\
\hline $\begin{array}{l}\text { Case A. Company } 1 \text { Sutures } \\
\text { strategic product maturing, but } \\
\text { still innovating market }\end{array}$ & $\begin{array}{l}\text { Uncertainty of future supply } \\
\text { Need for quality improvement } \\
\text { Cost pressure }\end{array}$ & $\begin{array}{l}\text { Stable supply } \\
\text { Improved quality } \\
\text { Better supply prices } \\
\text { Standardisation and simplification of } \\
\text { purchasing }\end{array}$ & $\begin{array}{l}\text { More testing costs to be incurred } \\
\text { Increased risk of dissemination of } \\
\text { secret information }\end{array}$ \\
\hline $\begin{array}{l}\text { Case B. Company } 2 \\
\text { Hexachloropentadiene strategic } \\
\text { product relatively fast growing } \\
\text { market }\end{array}$ & $\begin{array}{l}\text { Need for cost efficient deliveries } \\
\text { Need for quality improvement }\end{array}$ & $\begin{array}{l}\text { Better prices as well as supplementary } \\
\text { cost improvements } \\
\text { Improved quality }\end{array}$ & None \\
\hline $\begin{array}{l}\text { Case C. Company } 3 \text { Orange juice } \\
\text { bottleneck product market } \\
\text { nearing maturity }\end{array}$ & $\begin{array}{l}\text { Need for standardisation } \\
\text { Uncertainty of future supply } \\
\text { Cost pressure } \\
\text { Standardisation of recipes }\end{array}$ & $\begin{array}{l}\text { Standardisation leading to cost } \\
\text { effectiveness } \\
\text { Improved stability in production } \\
\text { output } \\
\text { Better purchasing prices }\end{array}$ & $\begin{array}{l}\text { Increased logistic costs } \\
\text { Slight increase in risk of dissemination } \\
\text { of secret information }\end{array}$ \\
\hline
\end{tabular}

\section{Three cases of change from single sourcing to multiple sourcing}

All cases where a strategy change from single towards multiple sourcing took place are considered by our respondents in the buying companies to be cases of products of a strategic nature (in terms of the portfolio models of Kraljic (1983), Bensaou (1999) and Gelderman and Van Weele (2003) these are products with a high supply risk and involving a substantial budget). Moreover they took place in markets tending to maturity, but still showing some product improvements. The motives for changing the sourcing strategy range from the need for quality improvement and cost pressure (cases A and C) to the need for cost efficient deliveries (case B), uncertainty of future supply (case A) and the need to standardise (case C). It seems that specifically in more innovative and faster changing markets (cases A and B) the uncertainty about the still rapidly changing environment and specifications makes quality a more prominent factor, whereas standardisation and cost pressure play a more important role in more mature markets. It is striking that these stated reasons coincide with the expected benefits. Even in the one case in which cost pressure was not mentioned explicitly as a motive (case B), cost improvement was still hoped for:

By changing to multiple sourcing, we hope to introduce more competitiveness among suppliers and thus get more benefit out of our negotiations (case B).

In some cases standardisation efforts were mentioned as a major reason for the strategy change. It may well be that buyers are actively trying to counterbalance the efforts of suppliers to develop captive markets:

Suppliers always try to improve on their products and change specifications up to a point that their product is not identical anymore to the ones offered by their competitors. We as buyers try to standardise to limit the range of products and send a strong signal that we do not want to buy anything at any price (case C).

The major concerns of the respondents deal with the fear that some elements of the total cost structure might be inversely affected. The concern about quality costs is larger in cases A and $\mathrm{B}$ since the cost inefficiencies of destandardized production items are here of major importance, as could be expected from the stated reasons for changing the supply strategy.

\section{Seven cases of change from multiple sourcing to single or dual sourcing}

The cases in which the inverse sourcing switch took place can be considered as mature markets and four out of seven as dealing with a "leverage product" (Kraljic, 1983; Bensaou, 1999), posing little supply risk and involving an important amount of money. In only one case (case E) the product was considered to bear a high supply risk. In all cases cost pressure or the need to improve the total cost of purchasing was cited as the main reason for changing strategies. Other expected positive outcomes vary from improved quality to increased reliability of deliveries. Increased mutual dependency and the risk of supply interruption are cited as inconveniences:

Of course, having less sources of supply entails a certain risk. Not only do you in the end become very dependant on one another, but some market knowledge also fades away over time (case I).

In some cases (D, E and I), purchasing managers believe that through single sourcing, secret information will be less likely to be spread on the market:

The identity of our recipes should not be known to our competitors. Limiting the number of suppliers is limiting the number of potential market leaks (case D).

The expected "improved supplier relationship" confirms the common belief of authors that in spite of increased cost pressure and lower purchase prices not splitting the purchased volume over more than one supplier or splitting it over less suppliers than previously leads to more trust among partners. Most purchasing managers consider such a relationship, based on hard facts and strict market (price and performance) comparison, to be "simpler", "better" and "more stable" than a relationship based on continuous negotiations:

You better devote time and money to real issues than to negotiations: how do we improve our mutual costs by jointly working at quality improvement, avoiding unnecessary warehousing costs or improving flexibility to customers (case J)

Reducing the supplier base was not only essential to become more interesting as a customer thus leading to better performance of suppliers, but also to be seen as a partner for future co-development (case D). 
Table III Cases in which a strategy change took place from multiple to single or dual sourcing

\section{Case characteristics strategy}

Case D Company 3 Flavours strategic product maturing market, but still innovating
Cost pressure

Supplier base reduction programme

Secrecy of information

\title{
Case E Company 4 Drinking Cost pressure
}

glasses bottleneck product mature Need for quality improvement market, little innovation, specific

items

\author{
Case F Company 5 Nickel leverage Cost pressure \\ product mature market global \\ market

Case G Company 5 Scrap iron Cost pressure
leverage product mature market
global market

Case H Company 4 Standard forwarding services leverage

Supplier base reduction programme Cost pressure product mature market European Need for improved flexibility market

Case I Company 6 Cokes waste Legal environment strategic product mature market, Cost improvement necessity innovating slowly global market

$\begin{array}{ll}\text { Case J Company } 2 \text { Phenol leverage } & \text { Cost pressure } \\ \text { product mature international } & \text { Need for availability of supply } \\ \text { market } & \end{array}$

Advantages expected to be gained Anticipated disadvantages

Improved quality of supplied product Increased risk of supply disruption in

Better purchase prices

Decreased risk of dissemination of Increased dependency on suppliers

secret information

Improved secrecy of information

Improved total cost (decrease of

handling and warehousing costs)

Improved flexibility of supply

Improved relationship with suppliers

Improved quality of product None

Better purchase prices

Less risk of dissemination of secret information

Improved relationship with suppliers Improved relationship with suppliers Improved flexibility leading to improved profitability of operations Improved relationship with suppliers Improved flexibility leading to improved profitability of operations

Improved management of operations Increased risk of supply disruption in emergency cases

Increased risk of supply disruption in emergency cases

Increased dependency on suppliers Higher purchase prices

Improved relationship with suppliers

Improved service quality

Decrease of indirect (administrative) costs

Improved relationship with suppliers Less risk of dissemination of secret information

Better image with local government Improved management of operations None Improved relationship with suppliers Improved service quality

Better supply prices
From our cases it would seem that cost pressure also stands out as a prime strategy change reason in mature markets and for leverage products (cases $\mathrm{F}$ through $\mathrm{H}$ ), whereas the quality and performance related benefits become as prevalent as cost pressure for strategic product buys (case D) and for bottleneck products (case E). The only services buy (case H) stands out as an exception. For strategic buys (case D) and for products which might pose future supply shortages (case I) assuring future supply and becoming not too dependant on a single source are major concerns after the single source policy has been put in place.

\section{Discussion}

The motivations and expected results of both strategy changes are visualised in Figures 1 and 2. These figures are read as follows. Everything, which is presented above the central lozenge, must be considered as a reason for the change indicated inside. Underneath the lozenge expected
Figure 1 Change of sourcing strategy from single sourcing to dual or multiple sourcing

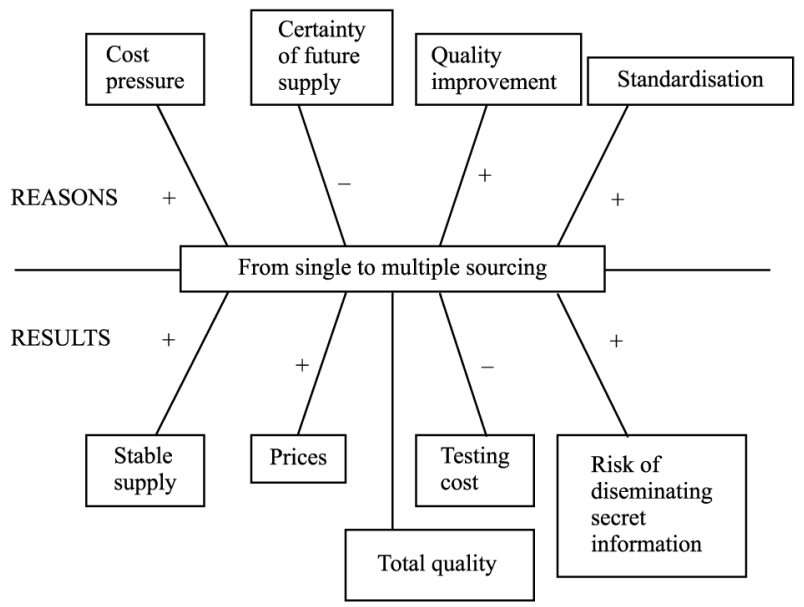


Figure 2 Change of sourcing strategy from multiple sourcing to a smaller number of suppliers (dual or single sourcing)

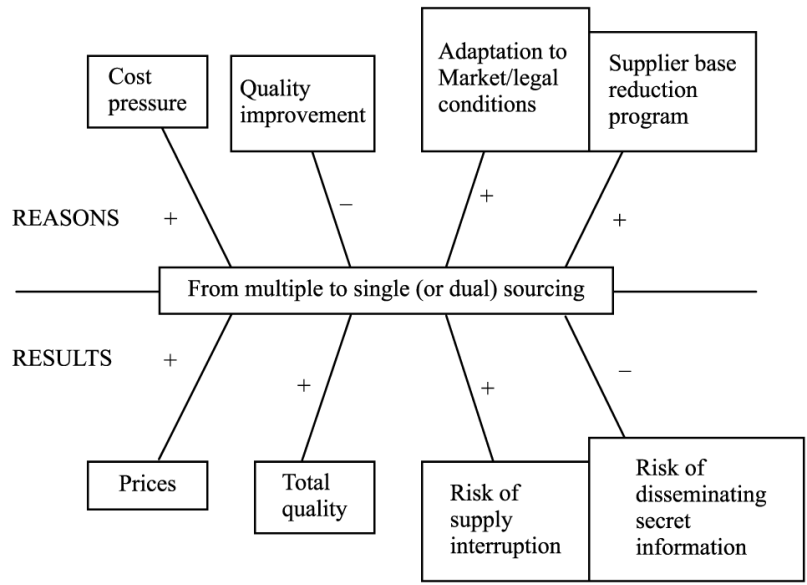

consequences of the strategy change are depicted. A " + sign" next to an arrow indicates a positive relationship between either the motive for the change and the change or between the change and its expected consequence, A " - sign" depicts an inverse relationship. We have in both figures only taken into account the motives and consequences which were not only explicitly mentioned by all interviewees in a particular case, but also confirmed by the verifying documents. Whether a factor was considered to be a "motivator" or a "result" was left up to the interviewees, as well as the positive or negative wording of their feelings about the observed facts (for instance one interviewee might see something as "a gain" whereas another as "a loss to be feared"). We are thus aware of the fact that some subjectivity will have played a role in the labelling of the figures, but we have checked that no inconsistencies occur. In general, if a majority (although this is also a relative notion given the small number of cases) of the interviewed people worded something as positive, we have done likewise and vice versa.

When comparing these two figures with one another, three identical "influencing" factors become apparent: cost cutting and quality improvement, assuring future supply and concerns about the secrecy of information shared with suppliers. The way in which they seem to operate however is quite different. The first of those three factors (dealing with cost pressure as a factor of influence) tends to be indifferent to the direction in which the strategy change takes place. It is mentioned explicitly across (nearly) all cases. Moreover cost benefits can be the result of both a supplier base reduction, or of efforts to find more suppliers for a particular product or service. Both other factors (assurance of supply and secrecy of information), however, are inversely related to the strategy change mentioned in the central lozenge of Figures 1 and 2. Let us investigate this in somewhat more detail.

First, the same cost cutting and quality improvement reasons are associated with strategy changes in both directions. Purchasing managers apparently change sourcing strategies whenever (and maybe only when and because) they expect cost benefits or quality improvement to result from it. And it seems to work both ways. In our opinion, this can only be explained by looking at the contextual factors of the sourcing strategy change, which are the case characteristics themselves as Dubois and Gadde (1996) have always pretended. Some of these also feature separately in the Figures, such as standardisation in Figure 1 and the existence of a supplier base reduction program in Figure 2. Respondents clearly did not make a lot of distinction between objectives to be obtained and ongoing company purchasing restructuring efforts. It proves on the one hand that this is a living and dynamic subject indeed, and on the other hand that we will certainly need to investigate the cases further over longer periods of time to discover the underlying motives and structures and to explain the observed phenomena in more depth.

For instance, case D is an excellent example of the fact that long term concerns and market dynamism play a role when taking those strategic decisions. After having reduced the number of flavour suppliers, the company is very satisfied with the increased supplier quality performance and the eagerness to develop new flavours to satisfy the rapidly changing taste of consumers. However, there is some concern that there will undoubtedly come a moment at which none of the remaining suppliers will be capable of developing a specific new flavour for them. At that moment the fear exists that none of the actually dumped suppliers will be very willing to help them, or only at additional costs. This is the main reason why the company did not want to reduce the number of suppliers further than the actual level of four. They hope that those four suppliers will be able to perform the necessary development and innovation in about 99 per cent of all future cases.

Second, the assurance of future supply seems to be an important factor in every case. Although it is a factor mentioned as a reason for changing from single to multiple sourcing (Figure 1), it also pops up as a major concern of the inverse strategy. Apparently, committing oneself to a more limited number of supply sources is considered by our purchasing respondents as something like putting your eggs in one basket, thus increasing the risk of supply uncertainty when the relationship turns sour. This is in line with what most research so far has observed (Haywood, 2001; Talluri and Narasimhan, 2003; Liu et al., 2005).

Third, secrecy of information is very often a major concern when changing a sourcing strategy, although until now it was rarely mentioned in literature. Limiting the number of suppliers is seen as helping in safeguarding information, which competitors (of both suppliers and buyers) might be interested in.

The first observation merits some extra thought. Why do purchasers choose opposite strategies to achieve the same result, namely cost cutting? Based on the evidence of our cases, the main reason for this can probably be found in the different portfolio positions of the products in the observed cases.

In the cases where increasing the number of suppliers is the preferred strategy, the products are either of a "strategic" or of a "leverage" nature. Their common characteristic in terms of portfolio management is a high financial stake. According to Gelderman and Van Weele (2003), customers will in these circumstances try to use their leverage to the maximum by either looking for alternative suppliers (for strategic products, and certainly when products enter the maturity cycle of their life cycle) or by simply standardising (as in the case of leverage and bottleneck items). The still rather innovative nature of 
some products explains why buyers would certainly fear the risk of disseminating secret or company-linked information in those cases (as in cases A and C).

Situations in which customers intend to limit their number of suppliers are mostly situations of leverage items (cases F, $\mathrm{G}, \mathrm{H}$, and $\mathrm{J}$ ). Although negotiating with the alternative sources on the market is considered to be a good method of decreasing market related prices, most buyers prefer not to split volumes too much. This might explain cost cutting efforts to be directed towards using less sources of supply (as in Figure 2), while at the same time improving relationships with preferred vendors on the market. The one strategic product in this category (flavours in case D) is a case where the enormous differentiation of items bought and their constant innovation necessitates a constant effort to standardise and to reduce the number of suppliers to achieve better quality (and although not mentioned) standardisation.

$>$ A potential explanation of these dynamic changes may well be the evolutionary path of a specific product through its own product life cycle. Cases in Table II and Figure 1 are "maturing, yet innovating", while the markets in Table III and Figure 2 are mostly considered to have already reached the maturity stage. In a maturing market, buyers still face the problem of diverging product specifications and multiple uses in their own factory. Products are often specifically designed for that use only and thus become "specialities". One source of supply will not always be the best solution for keeping the lid on costs, because suppliers will then consider the customer too much as a "captive market" (not readily wanting to stop buying from them). So buyers will look for more suppliers, thus giving the indication that the products bought are more "commodities" than "specialities". In a mature market on the other hand, products are already "commodities". Playing out suppliers against one another is cost effective, but does not necessarily lead to improved service and total cost, or to better prices. Thus efforts to diminish the number of suppliers, certainly on globalising (see cases F, G and $\mathrm{I}$ ) or regional (cases $\mathrm{H}$ and $\mathrm{J}$ ) markets, will be undertaken.

We hypothesise on the dynamic path a product might thus follow in purchasing portfolio perspective. Buyers will constantly have cost cutting efforts as their main objective throughout this evolutionary path, except in the first stages when supplying the product altogether will be their major concern. This is shown in Figure 3.

New products are probably "bottleneck products" or "strategic products" once they start being bought. At that moment little or no alternatives exist and the main concern of the buyer is getting the product or developing the best possible solution for an innovative supply problem. When the market starts developing ever-new product and service attributes, a number of new sources of supply become available, offering different or deviating specifications. As the inherent supply risk then decreases, products move more to the left of the diagram. When the product nears the maturity stage of its life span, this array of ever changing specifications starts levelling off.

Products become less "strategic" in nature and near the "leverage" or "low cost" quadrant of the Figure, depending on whether they are relatively important for the buying company in terms of financial risk involved. Buyers then become even more aware of the necessity to standardise and thus cut costs. This can only be done by introducing new sources of supply next to the earlier preferred ones and explains part of Figure 1. Gradually, as more and more sources are available on the market and products will certainly enter the "leverage product" area of the portfolio matrix or stay in the "low cost item" quadrant. Buyers then need to weed out unnecessary costs by reducing the number of suppliers, certainly in the case of "low cost items", but also for "leverage items". Splitting volumes too much is counterproductive. As in Figure 2 we have a mix of cases in which the buying company goes to one (or dual) sources (and thus keeps competition alive), so we can observe this part of the dynamism as well.

When mapping their products into the matrix, the managers in mature markets mentioned some doubt with respect to the future direction (cases $\mathrm{F}, \mathrm{G}, \mathrm{H}$, and J). They do not know whether, or if at all, in the decline stage of the PLC, an innovative new product will replace the actual one. The strongest evidence for our theory stems from the movements portrayed by our respondents in cases C, E, and I. These products are clearly situated in a state of, or need for "transition".

This theory supports the strategic intentions of buyers to alter the position of products in the portfolio matrix, as stated by Gelderman and Van Weele (2003). Next to the buyer's intentions, market dynamics may play a role as well in this process. It is a combination of strategic intentions by both supply and demand, which shape the dynamic nature of a market. It explains why for the same product different sourcing strategies are employed during the life cycle of a product and why over a longer period of time deviating and often contradicting evidence on sourcing strategies may be found in the literature (Dubois and Gadde, 1996; Araujo et al., 1999). Anyway, the dynamic nature of sourcing strategies makes it more interesting to investigate.

Our cases also reveal a form of tension in sourcing strategy changes. On the one hand, there will be inertia and on the other a drive for change. First, there is of course internal inertia due to the costs associated with the switching process itself. Changing from one source of supply to another is indeed a costly activity: it entails adapting processes, communication lines, ways of doing things and moreover changing all of the non-written personal adaptation modes of a company ant its personnel to the supplier and its personnel. The outcome of the supplier switch is further uncertain. Second, in highly regulated industries (such as food or hazardous chemicals) the changing of suppliers might be discouraged by rules and regulations to which organizations have to adhere. These pose a supplementary cost and create an additional administrative barrier to strategy changes.

At the same time, changing suppliers or supplier numbers altogether is clearly stimulated, or at least supported, by outside factors, of which cost pressure is of course the most prevalent one. But market changes, such as mergers and acquisitions and changes in trade relationship between nations or regions also play a role. These external factors necessitate companies to standardize, to reduce their supplier base or to actively engage in more international sourcing activities, leading to a potential change of sourcing strategy. Thus, sourcing strategy changes are situated at the crossroads of contradictory drivers. 
Figure 3 Dynamic path of a product in the purchasing portfolio matrix

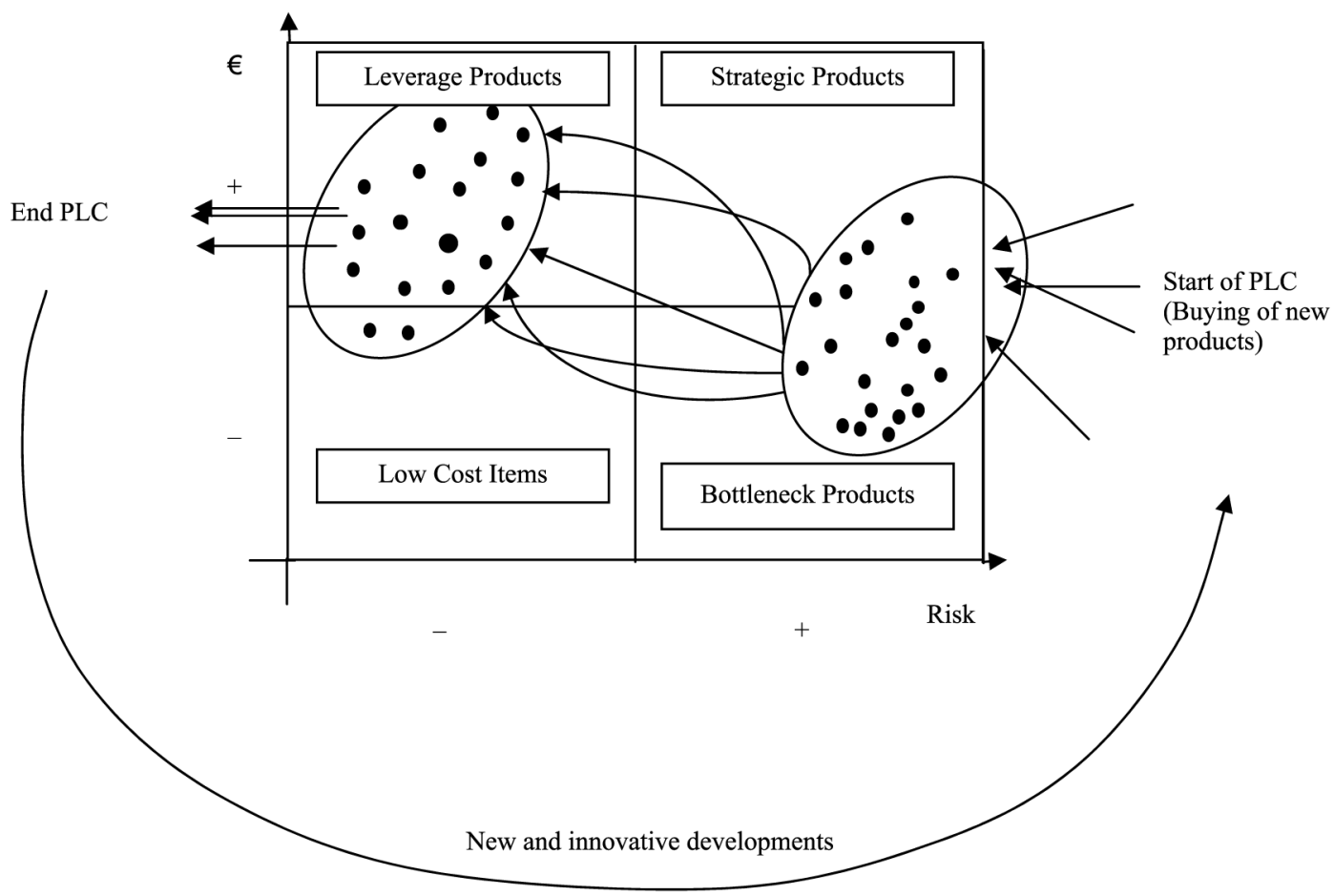

\section{Conclusions, recommendations and implications for further research}

Changing from one to more than one supplier and vice versa is one the major strategic decisions purchasing managers constantly faces. This case research did not really come up with any new factor of influence on whether to choose a single or a multiple supply strategy compared to existant research (e.g. Zeng, 2000). New paradigms might thus be very hard to find.

Our research, however, did find out that the importance of the different motives for strategy change clearly varies with varying market situations. As such, when companies change from single to multiple sourcing uncertainty about the still rapidly changing environment and about the specifications is put forward as a determining factor of influence in the more innovative and faster changing markets, whereas standardisation and cost pressure apparently play a more important role in more mature markets. Equally, when a supplier base reduction strategy is implemented, cost pressures dominate in mature markets, whereas quality is a more determining factor on markets, which are not fully mature or global yet.

Moreover, the dynamic nature of the process also became apparent. Our research confirms that purchasing strategy changes do take place very erratically over time and in the both directions. Managers could do a better job in planning these moves. Cost pressure, for instance, may lead to both reducing the number of suppliers and to increasing it, whereas more qualitative and logistical concerns mostly lead to a need for reducing risks by going to less sources of supply. We have tried to explain this difference. It may be due to the strategic intentions of buyers (Gelderman and Van Weele, 2003), but also to the changing nature of the markets from which companies buy. In that sense, we have proposed a model of change linking the portfolio matrix and buyers' intentions for specific types of products to the life cycle of a product on the supply market (Figure 3).

Research on the validity of this model still needs to be invigorated and expanded, as the number of cases is rather small and as they are very diverse in nature. This needs to be done by novel and deeper investigation into the matter. Four research avenues seem very promising to us.

First, the interplay of both strategic intentions of buyers on the one hand and the strategies followed by the supply side (creating partially the product life cycle of products) needs further investigation. Linking the life cycles of purchased products to purchasing and marketing strategies is interesting because it clearly also has a reference to the ways in which markets operate and value is created through innovation. A multidisciplinary research project investigating suppliers and buyers in specific cases as well as the supply (or demand) chain in different markets can achieve this. We only looked at one side of the market in this exploratory research effort.

Furthermore, research efforts can in the future be directed more to longitudinal research in which the total life span of products is covered. This would present the opportunity to either validate or invalidate our major proposition presented in Figure 3 and to explain more confidently the diversity of cases (which we have also observed). This could eventually be linked to research in the field of "world class excellence" in purchasing by indicating whether and how "excellence" changes in nature over time.

Moreover longitudinal case research also poses the great advantage that the different stages in the strategy change process may become visible. As such, a stage like model of strategy change might be developed and compared to likewise models in other functions of the company. 
Finally, our research was exploratory in nature. The development of different hypotheses on influencing contextual factors and their interplay has to be furthered. The use of a multi-method research approach might shed more light on the observed phenomena and might lead to "if ... then" type of recipes for purchasing strategies.

Notwithstanding its qualitative character, this study implies some important messages for managers. First, purchasing managers and their staff should question their present sourcing strategy. More specifically, when strategy changes (from single to multiple or vice versa) are proposed, a clear strategy discussion should take place on the pros and cons as well as on the expected performance impact. The "fit" of this decision with the overall purchasing strategy and with the changing market conditions (drivers) must be evaluated. Second, the annual purchasing audit should include an overview of the sourcing moves and their attributed benefits. In fact more insight is needed into this type of strategy changes. Companies cannot accept such changes to be undertaken driven by "fashion" or because the "reverse" strategy did not pay off. A sourcing change might have quality and intellectual property implications, and hence needs to be managed hands-on. A portfolio perspective might guide in this endeavour.

\section{Notes}

1 The purchasing situation is looked upon from a portfolio perspective as prescribed by Kraljic (1983) and Bensaou (1999), which according to several authors now dominates the everyday life of industrial buyers and which are dynamic in nature (Cox and Lamming, 1997; Cox, 2001; Gelderman and Van Weele, 2003).

$2 \mathrm{Up}$ to our knowledge, sourcing switches have only been studied by Liu et al. (2005). However, these authors merely approach the subject from a marketing perspective looking at how buyers' value perceptions change when "moving" towards multiple sourcing.

\section{References}

Araujo, L., Dubois, A. and Gadde, L.E. (1999), "Dyadic business relationships within a business network context", Fournal of Marketing, Vol. 58 No. 1, pp. 1-15.

Asmus, D. and Griffin, J. (1993), "Harnessing the power of your supplier", The McKinsey Quartely, Vol. 37 No. 3, pp. 63-78.

Bensaou, M. (1999), "Portfolios of buyer-supplier relationships", Sloan Management Review, Vol. 40 No. 4, pp. 35-44.

Bhote, K.R. (1989), Strategic Supply Management, Amacom, New York, NY.

Biong, H., Parvathiar, A. and Waithe, K. (1996), "Why do some companies not engage in partnering relationships?", Proceedings of the 12th Annual IMP Conference, Karlsruhe, pp. 733-54.

Brandes, H. and Lilliecreutz, J. (1997), “Outsourcing: success or failure?", European fournal of Purchasing and Supply Management, Vol. 3 No. 2, pp. 63-77.

Brierly, S. (2001), "Beyond the buzzword: single sourcing", Intercom, Vol. 49 No. 1, pp. 15-18.
Buttack, P. (2001), "Introduction to single sourcing", Intercom, Vol. 48 No. 4, pp. 26-30.

Carter, P.L., Carter, J.R., Monckza, R.M., Slaight, T.H. and Swan, A.J. (2000), "The future of purchasing and supply: a ten-year forecast", Fournal of Supply Chain Management, Vol. 36 No. 1, pp. 14-26.

Clayton, R. (1998), "Insource or outsource?", Electronic Publishing, Vol. 22 No. 5, pp. 53-4.

Cooke, J.A. (1998), “To outsource or not to outsource?", Logistics Management and Distribution Report, Vol. 37 No. 10, pp. 57-8.

Cox, A. (2001), "Understanding buyer and supplier power: a framework for procurement and supply competence", fournal of Supply Chain Management, Vol. 37 No. 2, pp. 8-15.

Cox, A. and Lamming, R. (1997), "Managing supply in the firm of the future", European fournal of Purchasing and Supply Management, Vol. 3 No. 2, pp. 51-62.

Dirks, D., Huchet, J.F. and Ribault, T. (2000), Fapanese Management in the Low Growth Era, Springer Verlag, Hamburg.

Dubois, A. and Gadde, L.E. (1996), "Purchasing behaviour during three decades", Proceedings of the 12th Annual IMP Conference, Karlsruhe, pp. 805-7.

Eisenhardt, K. (1989), "Building theories from case study research", Academy of Management Review, Vol. 14, October, pp. 532-50.

Ellram, L. and Billington, C. (2001), "Purchasing leverage considerations in the outsourcing decision", European Fournal Of Purchasing and Supply Management, Vol. 7 No. 1, pp. 15-28.

Ford, D. (2002), The Business Marketing Course, John Wiley \& Sons, Chichester.

Freeman, V.T. and Cavinato, J.L. (1990), "Fitting purchasing to the strategic firm: frameworks, processes and values", Fournal of Purchasing and Materials Management, Vol. 26 No. 4, pp. 6-10.

Gadde, L.E. and Hakansson, H. (2001), Supply Network Strategies, John Wiley \& Sons, Chichester.

Gadde, L.E. and Mattson, L.G. (1987), "Stability and change in network partnerships", International fournal of Research in Marketing, Vol. 4 No. 1, pp. 29-41.

Gelderman, C.J. and Van Weele, A.J. (2003), "Handling measurement issues and strategic directions in Kraljic's purchasing portfolio model”, fournal of Purchasing and Supply Management, Vol. 9 No. 4, pp. 207-16.

Han, S.L., Wilson, D.T. and Dent, S.P. (1993), "Buyersupplier relationships today", Industrial Marketing Management, Vol. 22 No. 4, pp. 331-8.

Haywood, J.B. (2001), The Outsourcing Dilemma: The Search for Competitiveness, Pearson Education, Upper Saddle River, NJ.

Hines, P. (1995), "Network sourcing: a hybrid approach", International fournal of Purchasing and Materials Management, Vol. 31 No. 2, pp. 18-24.

Hirakubo, N. and Kublin, M. (1998), "The relative importance of supplier selection criteria: the case of 
electronic components", International fournal of Purchasing $\mathcal{E}$ Materials Management, Vol. 34 No. 2, pp. 19-25.

Juttner, U., Christopher, M. and Baker, S. (2007), "Demand chain management-integrating marketing and supply chain management", Industrial Marketing Management, Vol. 36 No. 3, pp. 377-92.

Kelle, P. and Miller, P.A. (2001), "Stockout risk and order splittin", International fournal of Production Economics, Vol. 71 Nos 1-3, pp. 407-16.

Keough, M. (1993), "Buying your way to the top", McKinsey Quarterly, Vol. 37 No. 3, pp. 41-62.

Kraljic, P. (1983), "Purchasing must become supply management", Harvard Business Review, Vol. 61 No. 5, pp. 109-17.

Kulchitsky, T.D. (1998), "Single sourcing and supplier certification: performance and relationship implications", Industrial Marketing Management, Vol. 27 No. 9, pp. 73-82.

Larson, P.D. and Kulchitsky, T.D. (1998), "Single sourcing and supplier certification: performance and relationship implications", Industrial Marketing Management, Vol. 27 No. 1, pp. 71-84.

Liu, A.H., Leach, M.P. and Bernhardt, K.L. (2005), "Examining customer value perceptions of organizational buyers when sourcing from multiple venders", fournal of Business Research, Vol. 58, pp. 559-68.

Lynch, C. (2001), "Developing a strategy for outsourcing", Logistic Manangement and Distribution, Vol. 40 No. 6, pp. T3-T7.

Miles, M.B. and Huberman, A.M. (1994), Qualitative Data Analysis, Sage Publications, Thousand Oaks, CA.

Owens, C., Swift, S. and Coe, B.J. (1994), "Sourcing preference scale", Industrial Marketing Management, Vol. 23 No. 2, pp. 171-80.

Pfaffman, E. and Stephan, M. (2001), "How Germany wins out in the battle for foreign direct investment: strategies of multinational suppliers in the car industry", Long Range Planning, Vol. 34 No. 3, pp. 336-55.

Porter, A.M. (1999), "Single sourcing: some love it, some fear it”, Purchasing, Vol. 126 No. 9, pp. 22-5.

Quayle, M. (1998), "Impact of strategic procurement in the UK governement sector", International fournal of Public Sector Management, Vol. 11 No. 5, pp. 397-414.

Quayle, M. (2002), "Purchasing policy in Switserland: an empirical study of sourcing decisions", International Business Review, Vol. 44 No. 4, pp. 205-37.

Richardson, J. (1993), "Parallel sourcing and supplier performance in the Japanese automobile industry", Strategic Management fournal, Vol. 14 No. 5, pp. 339-50.

Schorr, J.E. (1992), Purchasing in the 21st Century, Oliver Wight Publications, Brattleboro, VT.

Segal, N.M. (1989), "Implications of single versus multiple buying sources”, fournal of Marketing Management, Vol. 18 No. 4, pp. 163-78.

Sriram, V. and Mummalaneni, V. (1990), "Determinants of source loyalty in buyer-seller relationships", fournal of Purchasing and Materials Management, Vol. 26 No. 4, pp. 21-6.
Stork, K. (1999a), "A best practice that should be used more: single sourcing", Purchasing, Vol. 127 No. 4, pp. 27-8.

Stork, K. (1999b), "Single sourcing (part II)", Purchasing, Vol. 127 No. 5, pp. 32-3.

Sugihara, S. and Tanaka, T. (1994), Economic Thought and Modernization in Japan, Edward Elgar, Cheltenham.

Swift, C.O. (1995), "Preferences for single sourcing and supplier selection criteria", Fournal of Business Research, Vol. 32, pp. 105-11.

Talluri, S. and Narasimhan, R. (2003), "A methodology for strategic sourcing", European fournal of Operations Research, Vol. 154, pp. 236-50.

Towill, D.R. (1997), "The seamless supply chain: the predator's strategic advantage", Internatioanl fournal of Technology Management, Vol. 13 No. 1, pp. 37-56.

Treleven, M. (1987), "A management tool for the quality supplier", fournal of Purchasing and Materials Management, Vol. 26 No. 4, pp. 2-7.

Watts, C.A., Kim, K.Y. and Hahn, C.K. (1995), "Linking purchasing to corporate competitive strategy", International Fournal of Purchasing and Materials Management, Vol. 31 No. 1, pp. 2-8.

Yeung, H. (1995), “Qualitative personal interviews in international business research: some lessons from a study of Hong Kong transnational corporations", International Business Review, Vol. 4 No. 3, pp. 313-39.

Zeng, A.Z. (2000), "A synthetic study of sourcing strategies", Industrial Management \& Data Systems, Vol. 100 Nos 5/6, pp. 219-26.

\section{Further reading}

Douglas, M. (2001), "Move it, or lose", Frontline Solutions, Vol. 2 No. 6, pp. 18-22.

Håkansson, H. and Gadde, L.E. (1994), "The changing role of purchasing: reconsidering three strategic issues", European fournal of Purchasing and Supply Chain Management, Vol. 1 No. 1, pp. 27-35.

Håkansson, H. and Snehota, I. (1995), "The burden of relationships", Proceedings of the 11th IMP Conference, Manchester, pp. 522-36.

Matthyssens, P. and Vandenbempt, K. (2003), "Cognition-incontext: reorienting research in business market strategy", Fournal of Business \& Industrial Marketing, Vol. 18 Nos 6/7, pp. 595-606.

\section{Appendix. Interview guide}

\section{Identification issues}

- Short description of company activities.

- Type of sourced products.

- Company size indicators.

- Respondents experience and tenure.

\section{Motives and hindrances}

1 Identification of different sourcing mode switch cases.

2 Identification of two best-informed persons (see Table I for identification of company function). 
3 Type of product.

4 For each of the cases:

- Previous sourcing strategy and new one.

- Nature of the change.

- Reasons for change.

- Objectives (intended results).

- Barriers and hindrances during the change process.

- Context of the switching process.

\section{Achieved results}

- Impact on costs and prices.

- Impact on quality.

- Impact on relationships with suppliers.

- Impact on innovative capability.

- Impact on logistics stability.

\section{About the authors}

Wouter Faes is a teaching assistant of marketing and purchasing at the University of Hasselt, Belgium and is a management trainer and purchasing strategy consultant. His work has been published in the Fournal of Purchasing and Supply Management, Industrial Marketing Management, Advances in International Marketing and many other journals.

Paul Matthyssens is professor of strategic management at the University of Antwerp. He consults companies and trains managers on market strategy. His work has been published in, among others, the fournal of Purchasing and Supply Management, Industrial Marketing Management, Technovation, Fournal of Business \& Industrial Marketing and International Marketing Review. Paul Matthyssens is the corresponding author and can be contacted at: paul.matthyssens@ua.ac.be

To purchase reprints of this article please e-mail: reprints@emeraldinsight.com Or visit our web site for further details: www.emeraldinsight.com/reprints 